Article

\title{
Resilience of Aspergillus westerdijkiae Strains to Interacting Climate-Related Abiotic Factors: Effects on Growth and Ochratoxin A Production on Coffee-Based Medium and in Stored Coffee
}

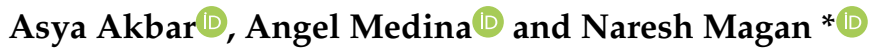 \\ Applied Mycology Group, School of Water, Energy and Environment, Cranfield University, Cranfield, \\ Bedfordshire MK43 0AL, UK; asyaakbar@live.com (A.A.); a.medinavaya@cranfield.ac.uk (A.M.) \\ * Correspondence: n.magan@cranfield.ac.uk; Tel.: +44-1234-758308
}

Received: 30 July 2020; Accepted: 17 August 2020; Published: 20 August 2020

check for updates

\begin{abstract}
We examined the resilience of strains of Aspergillus westerdijkiae in terms of growth and ochratoxin A (OTA) production in relation to: (a) two-way interacting climate-related abiotic factors of water activity $\left(\mathrm{a}_{\mathrm{w}}, 0.99-0.90\right) \times$ temperature $\left(25-37^{\circ} \mathrm{C}\right)$ on green coffee and roasted coffee-based media; (b) three-way climate-related abiotic factors (temperature, 30 vs. $35{ }^{\circ} \mathrm{C}$; water stress, $0.98-0.90 \mathrm{a}_{\mathrm{w}}$; $\mathrm{CO}_{2}, 400$ vs. $1000 \mathrm{ppm}$ ) on growth and OTA production on a $6 \%$ green coffee extract-based matrix; and (c) the effect of three-way climate-related abiotic factors on OTA production in stored green coffee beans. Four strains of $A$. westerdijkiae grew equally well on green or roasted coffee-based media with optimum $0.98 \mathrm{a}_{\mathrm{w}}$ and $25-30{ }^{\circ} \mathrm{C}$. Growth was significantly slower on roasted than green coffee-based media at $35^{\circ} \mathrm{C}$, regardless of $\mathrm{a}_{\mathrm{w}}$ level. Interestingly, on green coffee-based media OTA production was optimum at $0.98-0.95 \mathrm{a}_{\mathrm{w}}$ and $30^{\circ} \mathrm{C}$. However, on roasted coffee-based media very little OTA was produced. Three-way climate-related abiotic factors were examined on two of these strains. These interacting factors significantly reduced growth of the $A$. westerdijkiae strains, especially at $35^{\circ} \mathrm{C} \times 1000 \mathrm{ppm} \mathrm{CO}_{2}$ and all $\mathrm{a}_{\mathrm{w}}$ levels when compared to $30^{\circ} \mathrm{C}$. At $35^{\circ} \mathrm{C} \times 1000 \mathrm{ppm} \mathrm{CO}_{2}$ there was some stimulation of OTA production by the two $A$. westerdijkiae strains, especially under water stress. In stored green coffee beans optimum OTA was produced at $0.95-0.97 \mathrm{a}_{\mathrm{w}} / 30{ }^{\circ} \mathrm{C}$. In elevated $\mathrm{CO}_{2}$ and $35^{\circ} \mathrm{C}$, OTA production was stimulated at $0.95-0.90 \mathrm{a}_{\mathrm{w}}$.
\end{abstract}

Keywords: Aspergillus; ochratoxin A; climate change; growth; carbon dioxide; temperature; water stress

\section{Introduction}

Coffee is an important economic export crop for many lower middle income countries (LMICs) in both South America, South East Asia and Africa. The production of both Arabica and Robusta coffee involves harvesting of the ripe cherries, fermentation and subsequent drying steps. During the latter phase, uneven drying can allow colonization by mycotoxigenic fungi and contamination with mycotoxins, especially ochratoxin A (OTA). This is predominantly due to the presence of species from the Aspergillus section Circumdati group, especially Aspergillus westerdijkiae. The other two important species in this group are Aspergillus ochraceus and Aspergillus steynii [1]. Other species that have been suggested to possibly contaminate coffee as well as other commodities such as cocoa and grapes are members of the Aspergillus section Nigri group (e.g., Aspergillus carbonarius). There are thus legislative limits for the maximum amount of OTA in both green and roasted coffee in many countries including the EU [2]. 
At the present time there has been significant interest in the impact that climate-related abiotic factors may have on the colonization of economically important commodities with mycotoxgenic fungi and mycotoxins $[3,4]$. It has been shown that changes in temperature $\left(4-5{ }^{\circ} \mathrm{C}\right)$, increased atmospheric $\mathrm{CO}_{2}$ (from 400 to $1000 \mathrm{ppm}$ ) and drought/flooding episodes would have significant impacts on agronomy and security and safety of such commodities [3,5,6]. There is little knowledge of the impact of such interacting climate-related abiotic conditions on the functioning of key ochratoxigenic fungi or on the capacity for OTA production both in vitro and in situ [7]. Certainly, the biodiversity of microbial communities will change during plant growth, and this may change the dominance of different microbial communities on such commodities when entering the drying and storage phases [8]. This also applies to coffee beans where contamination mainly occurs either prior to harvest as the cherries ripen or contamination from soil during drying after the fermentation process. Inoculum mainly resides in soil, and it has been shown that ochratoxigenic fungi such as $A$. ochraceus (=A. westerdijkiae) and Penicillium verrucosum are very tolerant of soil matric water potential stress, and are thus active in soil and able to effectively colonize crop debris, allowing the subsequent contamination of drying coffee beans and other commodities [9,10].

Recent studies with mycotoxigenic species such as Aspergillus flavus have shown that while the colonization of staple food grains such as maize has been relatively unaffected by interacting CC-related abiotic factors $\left(2-4{ }^{\circ} \mathrm{C}, 400\right.$ vs. $1000 \mathrm{ppm} \mathrm{CO}$ and drought stress) there has been significant impact on aflatoxin $B_{1}$ contamination $[3,4,11]$. Some studies have also suggested that there may be differences in the effects of such interacting abiotic factors on OTA production by $A$. westerdijkiae and A. carbonarius on coffee-based media [7]. Studies with Fusarium verticillioides and fumonisin production on maize between silking and maturity showed that the biomass of the pathogen increased but that toxin production was unaffected by use of elevated $\mathrm{CO}_{2}$ exposure. However, exposure of maize plants to drought stress $\times$ elevated $\mathrm{CO}_{2}$ exposure stimulated contamination of ripening maize cobs with fumonisins $[12,13]$. There is thus interest in the resilience of strains of $A$. westerdijkiae, which is considered to be mainly responsible for the OTA contamination of coffee under interacting climate-related abiotic factors.

The objectives of this study were thus to examine: (a) the effect of in vitro effects of two-way abiotic stress factors of $\mathrm{a}_{\mathrm{w}} \times$ temperature on four strains of $A$. westerdijkiae (B 2, CBS 121986, 2A3, C1/1); (b) the effect of three-way interacting climate-related abiotic factors (drought stress $\left(\mathrm{a}_{\mathrm{W}}\right) \times$ temperature $\left(4^{\circ} \mathrm{C}\right.$ above optimum $\times$ existing and elevated $\mathrm{CO}_{2}$ ) on in vitro growth and OTA production on coffee-based matrices by two strains (B 2, CBS 121986); and (c) to determine the in situ effects of these three-way climate-related abiotic factors on OTA contamination of stored raw coffee beans by these two strains of A. westerdijkiae.

\section{Materials and Methods}

\subsection{Fungal Isolate and Spores Preparation}

The strains used were all from the Aspergillus section Circumdati group. Initially, four strains of A. westerdijkiae (B 2, CBS 121986, 2A3, C1/1), all isolated from green coffee beans, were used in this study. These were all confirmed producers of ochratoxin A using coconut cream agar and a conducive Yeast Extract Sucrose (YES) medium and quantifying production after 10 days growth.

\subsection{Coffee-Based Agar Media Preparation}

Agar media were initially prepared from both green and roasted Arabica coffee beans to examine the effect of coffee extract type and environmental interacting factors on growth. This involved milling either $300 \mathrm{~g}$ of green Arabica or roasted Arabica coffee beans. These were placed into a flask containing $1 \mathrm{~L}$ of water and boiled for $30 \mathrm{~min}$ to obtain concentrated coffee extracts. A double layer of muslin was used to filter the resulting concentrated mixtures. These were used at $6 \%$ concentration and modified with glycerol/water solutions to obtain $\mathrm{a}_{\mathrm{w}}$ values of $0.99,0.98,0.95$ and 0.90 . A $2 \%$ technical agar 
(Thermo Fisher Scientific Oxoid Ltd., Basingstoke, Hampshire, UK) was added for solidifying the media prior to autoclaving at $121^{\circ} \mathrm{C}$ for $15 \mathrm{~min}$. The molten cooled agar media (green coffee extract agar (GCEA) and roasted coffee extract agar (RCEA)) were mixed and carefully poured into 9-cm Petri plates (approx. $17.5 \mathrm{~mL}$ per plate) in a sterile flow bench and allowed to cool. They were then stored in separate plastic bags at $4{ }^{\circ} \mathrm{C}$ until being returned to ambient conditions for inoculation. The final $\mathrm{a}_{\mathrm{w}}$ levels were checked with a Aqualab 4TE $\mathrm{a}_{\mathrm{w}}$ measuring meter (Decagon Devices, Inc., Pullman, WA, USA) and found to be within $0.003 \mathrm{a}_{\mathrm{w}}$ of the target level.

\subsection{Inoculation for In Vitro Studies on Coffee-Based Media}

The inoculum was prepared by growing each strain on the $6 \%$ GCEA at $30{ }^{\circ} \mathrm{C}$ for seven days. Spore suspensions were prepared by agitating the colony surface with a sterile spatula in $9 \mathrm{~mL}$ of sterile distilled water containing $0.05 \%$ Tween 80 . All treatments and replicates in the experiments were centrally point-inoculated with $7-10 \mu \mathrm{L}$ of the spore suspensions.

\subsection{Comparison of the In Vitro Resilience in Relation to $a_{w} \times$ Temperature Stress on Growth of Strains of} A. westerdijkiae on Green and Roasted Coffee-Based Agar Media

The GCEA and RCEA $\mathrm{a}_{\mathrm{w}}$ treatments were inoculated and incubated at 25,30 and $35{ }^{\circ} \mathrm{C}$ for 10 days. Growth of the colonies was measured in two directions at right angles to each other every two days. The colony radius ( $\mathrm{mm}$ ) vs. time (days) for each replicate of each strain under the different treatment conditions was plotted in Microsoft Excel. After data plotting, a linear model was used to calculate the relative growth rates ( $\mathrm{mm} /$ day). The growth rates were obtained as the slope of the line. The square of the linear correlation coefficients was $\geq 0.98$. The square of the linear correlation coefficients was $\geq 0.98$. At the end of the experiment the ochratoxin A production was quantified [7]. These studies were carried out with all four strains.

\subsection{In Vitro Effect of Climate Change Related Interacting Abiotic Factors on Growth and Ochratoxin A Production by the A. westerdijkiae Strains}

The experiments were conducted using only the 6\% GCEA as detailed previously with two strains of $A$. westerdijkiae (B 2, CBS 121986). The GCEA media were adjusted to $0.95,0.98$ and $0.99 \mathrm{a}_{\mathrm{w}}$, respectively. These were again autoclaved at $121^{\circ} \mathrm{C}$ for $15 \mathrm{~min}$, well-mixed, then approx. $17.5 \mathrm{~mL}$ was poured into $9-\mathrm{cm}$ sterile Petri plates, cooled and kept at $4{ }^{\circ} \mathrm{C}$ until use. The final $\mathrm{a}_{\mathrm{W}}$ levels were again checked with a water activity meter (Aqualab 4TE; Decagon Devices, Inc., Pullman, WA, USA).

Inoculated replicates and treatments were placed in plastic environmental chambers. Inoculated treatments of the same $\mathrm{a}_{\mathrm{w}}$ were enclosed together in the environmental chambers containing switchable valves at each end: one for $\mathrm{CO}_{2}$ intake and the other for exit. Two 500-mL beakers of glycerol/water solution with the same $a_{w}$ as the treatment were included in the chamber to maintain the same equilibrium relative humidity $(\mathrm{ERH})$ as the media $\mathrm{a}_{\mathrm{w}}$.

The chambers were flushed with either $5 \mathrm{~L}$ of air $\left(400 \mathrm{ppm} \mathrm{CO}_{2}\right)$ or $1000 \mathrm{ppm} \mathrm{CO}_{2}$ from a specialty gas cylinder (British Oxygen Company Ltd., Guilford, Surrey, UK; 1000 ppm $\mathrm{CO}_{2}$ cylinder) for about 10-15 $\mathrm{min}$, then the valves were sealed as detailed previously [14]. The environmental chambers were flushed every $24 \mathrm{~h}$. They were incubated for 10 days at 30 and $35^{\circ} \mathrm{C}$, and fungal growth was measured every two days. At the end of this period the cultures were removed for OTA analysis.

Growth of the colonies was measured as described previously every two days. Immediately after measurement the environmental chambers were flushed with the treatment $\mathrm{CO}_{2}$ for $10-15$ min and then sealed and incubated at the treatment temperature.

\subsection{In Situ Effect of Climate Change Abiotic Factors on Ochratoxin A Contamination of Stored Coffee Beans Inoculated with $A$. westerdijkiae and A. ochraceus Strains}

The in situ effect of interacting climate change abiotic factors on OTA production by the A. westerdijkiae strains was determined from stored raw coffee beans. Initially, $15 \mathrm{~kg}$ of raw Arabica coffee 
beans were gamma-irradiated at 12-15 Kgys (Synergy Health, Swindon, Berks, UK). This removed any microbial contamination from the surface and internally in the coffee beans. Plating these beans on Nutrient, malt extract or DG18 media showed no growth of any colonies. The coffee beans were used to build a moisture adsorption curve, which was prepared by the addition of known amounts of water to $10 \mathrm{~g}$ of green coffee bean sub-samples and stored at $4{ }^{\circ} \mathrm{C}$ for $24 \mathrm{~h}$ to allow water adsorption. The samples were then removed and, after equilibration at $25^{\circ} \mathrm{C}$, the $\mathrm{a}_{\mathrm{w}}$ of the hydrated coffee beans was measured using an Aqualab 4TE (Decagon Devices Inc., Pullman, WA, USA). The coffee bean samples were then dried at $110{ }^{\circ} \mathrm{C}$ for $24 \mathrm{~h}$ and kept in a desiccator at room temperature for $1 \mathrm{~h}$, then weighed to determine the moisture content.

Subsequently $325 \mathrm{~g}$ of irradiated raw coffee was weighed and water was added using the water adsorption curve to obtain the required target experimental $\mathrm{a}_{\mathrm{w}}$ levels of $0.97,0.95$ and 0.90 and kept at $4{ }^{\circ} \mathrm{C}$ for $24 \mathrm{~h}$ for equilibration with occasional shaking. They were then returned to laboratory temperature and allowed to equilibrate. The coffee beans were then divided into six sub-samples (50 g) in sterile solid substrate culture vessels (Magenta, Sigma-Aldrich Ltd., St. Louis, MO, USA) with permeable microporous membrane lids in a sterile flow bench.

Inoculation of coffee treatments was done for the each of the A. westerdijkiae strains (B 2, CBS 121986). The spore inoculum was obtained from cultures grown on $6 \%$ GCEA at $25^{\circ} \mathrm{C}$ for seven days and spore suspensions prepared as detailed previously. The concentration was adjusted by dilution to approx. $10^{4}$ spores/mL by using a hemocytometer. Using the methodology of Palacios-Cabrera et al. [15], $0.5 \mathrm{~mL}$ of spore suspension $\left(10^{4} \mathrm{CFUs} / \mathrm{mL}\right)$ of each strain was added to the $50 \mathrm{~g}$ of raw green coffee beans and shaken well. Twenty-five grams of coffee beans were used as a control at each $\mathrm{a}_{\mathrm{w}}$ level. The replicates of the same treatment were placed in the environmental chambers. The methodology was the same as that used for the in vitro studies for $\mathrm{CO}_{2}$ flushing of either air (400 ppm) or $1000 \mathrm{ppm}$ $\mathrm{CO}_{2}$. The inoculated coffee beans were incubated for 12 days at 30 and $35^{\circ} \mathrm{C}$. At the end of the storage period, the samples were all dried at $50{ }^{\circ} \mathrm{C}$ in a drying oven and then $25 \mathrm{~g}$ were ground for OTA analyses. These were stored at $-20^{\circ} \mathrm{C}$ until OTA extraction and quantification.

\subsection{Ochratoxin A Extraction and Quantification}

\subsubsection{In Vitro Studies}

Five plugs $(5 \mathrm{~mm})$ were taken across the colonies with a surface-sterilized cork-borer and transferred to 2-mL Eppendorf tubes and weighed. To each Eppendorf tube, $1000 \mu \mathrm{L}$ methanol was added. The samples were then shaken using a KS 501 digital orbital shaker for 30 min and centrifuged for $10 \mathrm{~min}$ at $15,000 \times g$. The supernatant was filtered and analyzed with the HPLC system (Agilent, Berks, UK). Twenty $\mu \mathrm{L}$ of the extracted toxin from the treatments and replicates were injected into the HPLC system. The conditions for OTA detection and quantification were as follows:

- Mobile Phase: Acetonitrile (57\%), water (41\%), acetic acid (2\%)

- Column: 120CC-C18 column (Poroshell 120, length $100 \mathrm{~mm}$, diameter $4.6 \mathrm{~mm}$, particle size 2.7 micron; 600 Bar)

- Temperature of column: $25^{\circ} \mathrm{C}$

- Excitation: $330 \mathrm{~nm}$

- Emission: $460 \mathrm{~nm}$

- Flow rate: $1 \mathrm{~mL} \mathrm{~min}^{-1}$

- Volume of sample injected: $20 \mu \mathrm{L}$

- Retention time: Approx. $2.49 \mathrm{~min}$

- Run time: 17 min

- Limit of detection: $0.01 \mathrm{ng} \mathrm{g}^{-1}$

- $\quad$ Limit of Quantification: $0.039 \mathrm{ng} \mathrm{g}^{-1}$ 


\subsubsection{In Situ Ochratoxin A Quantification}

For the in situ samples, initial clean-up was done using Neogen immunoaffinity columns (Neogen, Neocolumn method). Ten grams of milled of dried coffee beans were extracted with a $50 \mathrm{~mL}$ methanol/water (70:30) solution in 1\% sodium bicarbonate. The extracts were then filtered, and $5 \mathrm{~mL}$ were diluted with $45 \mathrm{~mL}$ phosphate buffered saline (PBS/Tween $(0.01 \% \mathrm{v} / \mathrm{v})$ and applied to an immunoaffinity column (Neogen Europe Ltd., Auchincruive, Ayr, Scotland, UK). Of this mixture, $1.5 \mathrm{~mL}$ was dried and $0.5 \mathrm{~mL}$ of acetonitrile/water (50:50) was added. The final extracts were analyzed by HPLC as detailed previously. The retention time of OTA under the conditions described was approximately $2.5 \mathrm{~min}$. The mobile phases used were acetonitrile (57\%), acetic acid (2\%) and water (41\%) [16].

\subsection{Statistical Analyses}

A full factorial design was applied for the two-way $(4 \times 5)$ factor experiments: water activity and temperature. For each treatment, a water activity $\times$ temperature combination was carried out in triplicate for growth rate and OTA production, and the experiment repeated once.

Normality was checked using a Kolmogorov-Smirnov test. Analysis of data including factors, responses and their interactions were examined by a Kruskal-Wallis (non-parametric) test if the data were not normally distributed. For normally distributed data, the datasets were analyzed using a Minitab 16 package (Minitab Inc., 2010. State College, PA, USA). The statistical significance level was set at $p \leq 0.05$ for all single and interacting treatment factors.

For climate-change-related factors, a full factorial design with three factors (water activity, temperature and $\mathrm{CO}_{2}$ ) was applied. Each treatment, $\mathrm{a}_{\mathrm{w}} \times$ temperature $\times \mathrm{CO}_{2}$ combination was carried out in triplicate, both for growth rate assessment and OTA production, then repeated once. Normality was checked using a Kolmogorov-Smirnov test. Analysis of data and the effects of $\mathrm{a}_{\mathrm{w}}$, temperature, $\mathrm{CO}_{2}$ and their interactions were examined by a Kruskal-Wallis (non-parametric) test if the data were not normally distributed. For normally distributed data, the datasets were analyzed using the Minitab 16 package (Minitab Inc., 2010. State College, PA, USA). The statistically significant level was set at $p \leq 0.05$.

\section{Results}

3.1. Comparison of Growth and Ochratoxin A Production by Strains of A. westerdijkiae on Green and Roasted Coffee-Based Media

Figures 1 and 2 show the relative growth rates of the four strains of $A$. westerdijkiae in relation to two-way interacting abiotic factors of $\mathrm{a}_{\mathrm{w}} \times$ temperature on coffee media made from both green and roasted coffee extracts. Overall there appeared to be slightly lower growth rates on the roasted than the green coffee-based media. Optimum growth was predominantly at $25^{\circ} \mathrm{C}$ and $0.98 \mathrm{a}_{\mathrm{w}}$ for all the strains on both nutritional media. All the four strains grew over the $\mathrm{a}_{\mathrm{w}}$ range $0.95-0.99$ on both media. However, growth was very slow at $0.90 \mathrm{a}_{\mathrm{w}}$ when compared to the other $\mathrm{a}_{\mathrm{w}}$ levels examined. Indeed, the CBS 121986 strain was unable to grow at $35^{\circ} \mathrm{C}$ and $0.90 \mathrm{a}_{\mathrm{w}}$. 

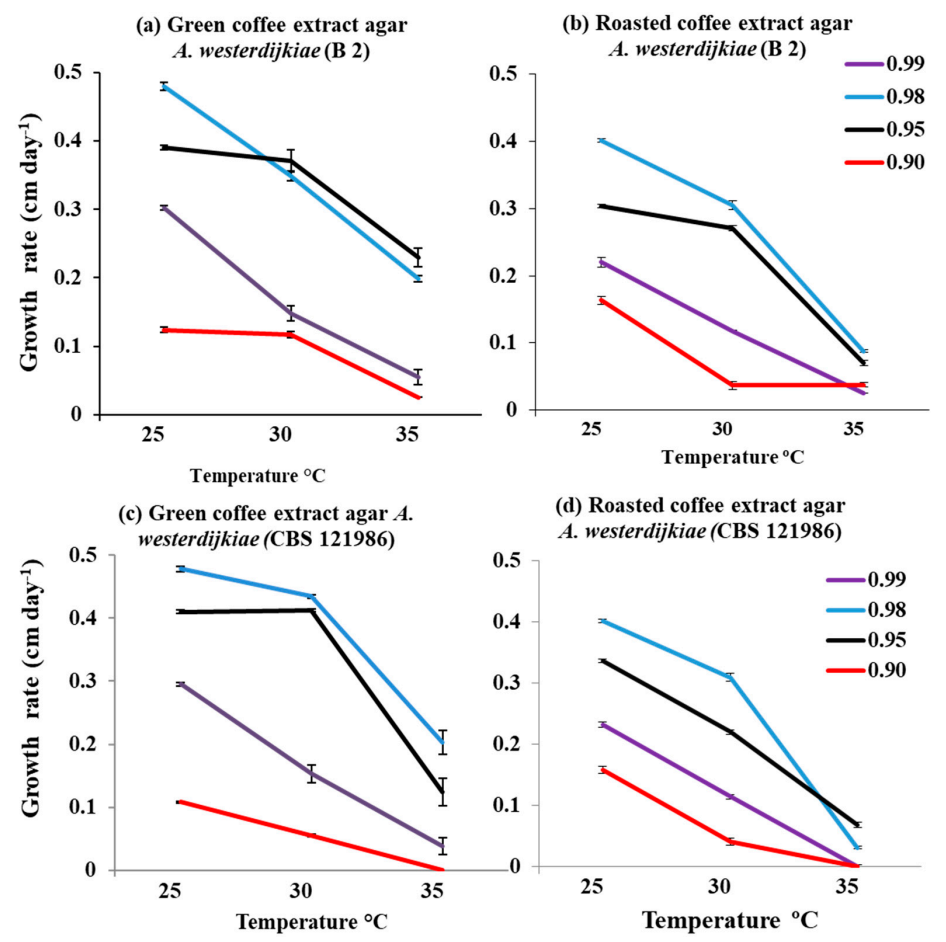

Figure 1. Effect of $(\mathbf{a}, \mathbf{c})$ green milled coffee extract (GCEA) and (b,d) roasted coffee extract (RCEA) media on growth $\left(\mathrm{cm} \mathrm{day}^{-1}\right)$ of two of the $A$. westerdijkiae strains in relation to different temperatures $\left(25,30,35^{\circ} \mathrm{C}\right)$ and water activity $\left(\mathrm{a}_{\mathrm{w}}\right)$ levels $(0.99,0.98,0.95,0.90)$ after 12 days colonization. Bars indicate SEM.
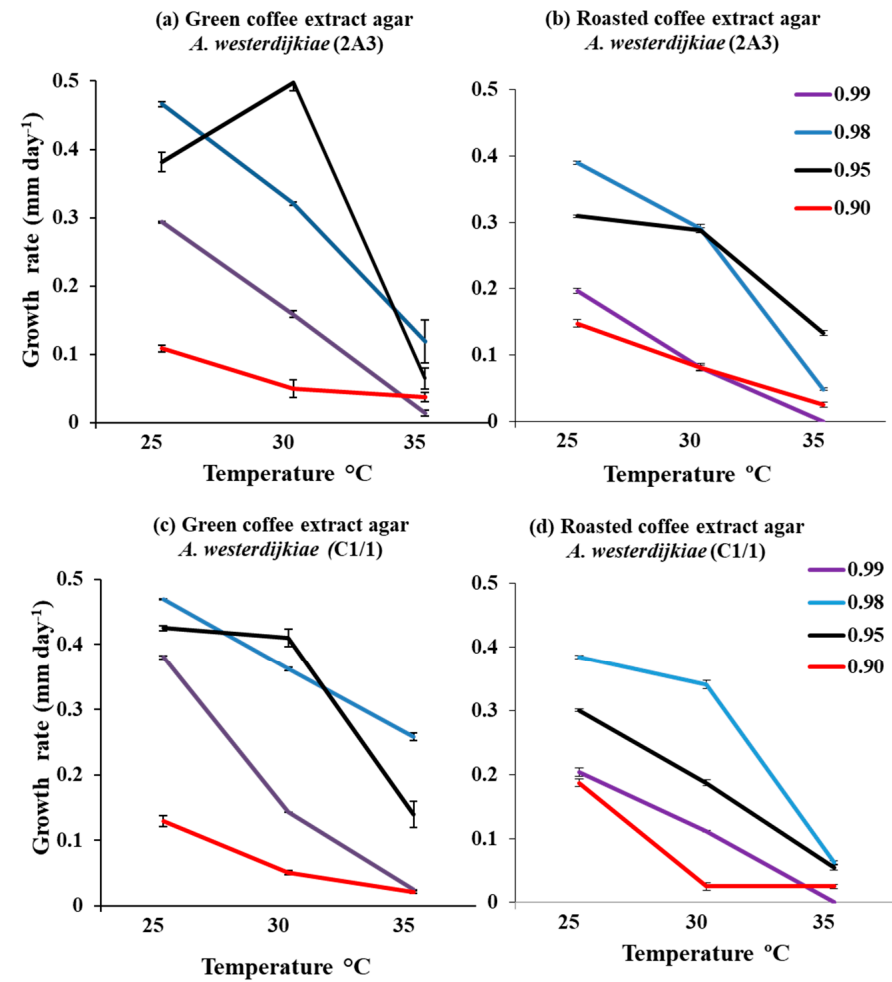

(d) Roasted coffee extract agar

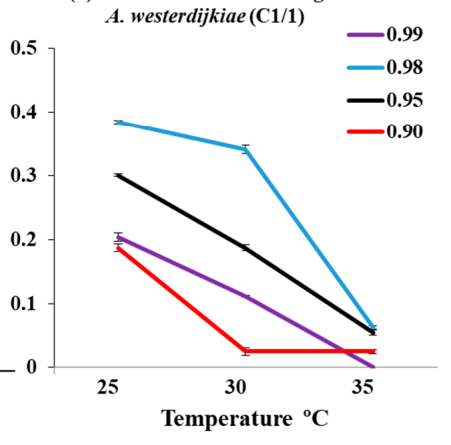

Figure 2. Effect of $(\mathbf{a}, \mathbf{c})$ green milled coffee extract (GCEA) and (b,d) roasted coffee extract (RCEA) media on growth $\left(\mathrm{cm} \mathrm{day}^{-1}\right.$ ) of the other two A. westerdijkiae strains in relation to different temperatures $\left(25,30,35^{\circ} \mathrm{C}\right)$ and water activity $\left(\mathrm{a}_{\mathrm{w}}\right)$ levels $(0.99,0.98,0.95,0.90)$ after 12 days colonization. Bars indicate SEM. 
Table 1 compares the actual OTA production by the four different strains of $A$. westerdijkiae in relation to growth under different $\mathrm{a}_{\mathrm{w}} \times$ temperature conditions on the two nutritional green and roasted coffee-based media. This shows that there was very little if any OTA production on the RCEA by any of the strains. In contrast, on the GCEA both B 2 and CBS 121896 strains produced the highest amounts of OTA with an optimum at $0.98 \mathrm{a}_{\mathrm{w}}$ and $30^{\circ} \mathrm{C}$. Lower amounts were produced at $0.95 \mathrm{a}_{\mathrm{w}}$ and $30{ }^{\circ} \mathrm{C}$.

Table 1. Effect of $\mathrm{a}_{\mathrm{w}}$, temperature and type of coffee extract medium on ochratoxin A (OTA) production $\left(\mathrm{ng} \mathrm{g}^{-1}\right)$ by the four strains of $A$. westerdijkiae examined.

\begin{tabular}{|c|c|c|c|c|c|c|c|}
\hline \multirow{2}{*}{\multicolumn{2}{|c|}{$\begin{array}{c}\text { Temperature }\left({ }^{\circ} \mathrm{C}\right) \\
\text { Strains/Medium/a } / \mathrm{a}_{\mathrm{w}}\end{array}$}} & \multicolumn{2}{|c|}{25} & \multicolumn{2}{|l|}{30} & \multicolumn{2}{|l|}{35} \\
\hline & & \multirow{2}{*}{$\begin{array}{c}\text { GCEA } \\
\text { ND }\end{array}$} & \multirow{2}{*}{$\begin{array}{c}\text { RCEA } \\
\text { ND }\end{array}$} & \multirow{2}{*}{$\begin{array}{c}\text { GCEA } \\
\text { ND }\end{array}$} & \multirow{2}{*}{$\begin{array}{c}\text { RCEA } \\
\text { ND }\end{array}$} & \multirow{2}{*}{$\begin{array}{c}\text { GCEA } \\
\text { ND }\end{array}$} & \multirow{2}{*}{$\begin{array}{c}\text { RCEA } \\
\text { ND }\end{array}$} \\
\hline A. westerdijkiae (2A3) & 0.99 & & & & & & \\
\hline & 0.98 & $4.1+1.1$ & $<$ LOQ & $8.3+3.9$ & $<$ LOQ & 10.3 & ND \\
\hline & 0.95 & $8.7+0.9$ & $2.6+0.2$ & $<$ LOQ & $<$ LOQ & 46.4 & ND \\
\hline & 0.90 & ND & $<$ LOQ & ND & ND & ND & ND \\
\hline \multirow[t]{4}{*}{ A. westerdijkiae (C1/1) } & 0.99 & $<$ LOQ & ND & ND & ND & ND & ND \\
\hline & 0.98 & $<$ LOQ & $<$ LOQ & $48.3+13.8$ & ND & 9.7 & ND \\
\hline & 0.95 & $32.4+0.4$ & $<$ LOQ & ND & ND & ND & ND \\
\hline & 0.90 & ND & $<$ LOQ & ND & ND & ND & ND \\
\hline \multirow[t]{4}{*}{ A. westerdijkiae (B 2) } & 0.99 & ND & ND & $40.3+5.1$ & ND & ND & ND \\
\hline & 0.98 & $9.4+5.2$ & $<$ LOQ & $1802.8+416$ & ND & $5206.3+433$ & ND \\
\hline & 0.95 & $3.7+0.2$ & $<\mathrm{LOQ}$ & $3.2+0.4$ & $<$ LOQ & $28.1+1.1$ & $<\mathrm{LOQ}$ \\
\hline & 0.90 & ND & ND & $<\mathrm{LOQ}$ & ND & $<$ LOQ & ND \\
\hline \multirow[t]{4}{*}{ A. westerdijkiae (CBS 121986) } & 0.99 & $<$ LOQ & ND & $<\mathrm{LOQ}$ & $<$ LOQ & ND & ND \\
\hline & 0.98 & $<$ LOQ & $<$ LOQ & $280.4+17.2$ & ND & $64.3+15.8$ & ND \\
\hline & 0.95 & $30.6+6.2$ & $<$ LOQ & $5.4+3.0$ & ND & 52.81 & ND \\
\hline & 0.90 & ND & $<$ LOQ & $<$ LOQ & ND & ND & ND \\
\hline
\end{tabular}

Key: GCEA, green coffee extract agar; RCEA, roasted coffee extract agar; <LOQ, below Limit of Quantification; ND, no toxin detected.

Table 2 summarizes the statistical analyses for mycelial growth and OTA production for the four strains of $A$. westerdijkiae at different $\mathrm{a}_{\mathrm{w}}$ levels on the two media types and different temperature conditions. The growth rate was significantly $(p<0.05)$ affected by $a_{w}(0.90,0.95,0.98$ and 0.99$)$ and temperature $\left(25,30\right.$ and $\left.35^{\circ} \mathrm{C}\right)$ for all strains. There was no significant difference between the other three strains examined (2A3, B 2, CBS 121986).

For OTA production, $\mathrm{a}_{\mathrm{w}}$ was a significant factor for all strains. There were similar amounts of OTA produced by $A$. westerdijkiae ( $\mathrm{C} 1 / 1)$ in the two media, although for the other A. westerdijkiae strains (2A3, B 2, CBS 121 986) there was a significant effect of medium type. Overall, the strains grew best at $25^{\circ} \mathrm{C}$ in both GCEA and RCEA and produced most OTA at $30^{\circ} \mathrm{C}$. The individual factors assayed (water activity, temperature, coffee medium type) as well as the interaction of $a_{w} \times$ temperature $\times$ coffee media (GCEA; RCEA) had a significant influence on growth and OTA production. Based on these results, only two strains (B 2, CBS 121986) were subsequently used to examine the effects of climate-related abiotic factors on growth and OTA production.

\subsection{In Vitro Effect of Interacting Climate-Related Abiotic Factors of Water Activity $\times$ Elevated $\mathrm{CO}_{2}$ $\times$ Temperature on Growth and OTA Production by Strains of A. westerdijkiae and A. ochraceus}

\subsubsection{In Vitro Effects of Interacting Climate-Related Abiotic Factors on Growth}

Figures 3 and 4 compare the growth rate for the two strains of $A$. westerdijkiae when exposed to air and elevated $\mathrm{CO}_{2}$ at different $\mathrm{a}_{\mathrm{w}}$ levels at 30 and $35^{\circ} \mathrm{C}$, respectively. At $30^{\circ} \mathrm{C}$ optimum growth was at 
$0.98 \mathrm{a}_{\mathrm{w}}$ then $0.99 \mathrm{a}_{\mathrm{w}}$, with lower growth rates at $0.95 \mathrm{a}_{\mathrm{w}}$. However, when temperature was elevated to $35^{\circ} \mathrm{C}$, growth was significantly influenced by both $\mathrm{a}_{\mathrm{w}}$ and $\mathrm{CO}_{2}(1000 \mathrm{ppm})$ and their interaction when compared to that at $30^{\circ} \mathrm{C}$. The two A. westerdijkiae strains grew much more slowly at $35^{\circ} \mathrm{C}$, with the fastest growth at $0.95 \mathrm{a}_{\mathrm{w}}$. Much less growth occurred at $0.98 \mathrm{a}_{\mathrm{w}}$, and there was practically no growth at $0.99 \mathrm{a}_{\mathrm{w}}$ in air or with elevated $\mathrm{CO}_{2}$.

Table 2. Summary of the statistical analyses of the effect of the factors on growth rate and OTA production by the four strains of $A$. westerdijkiae in relation to $\mathrm{a}_{\mathrm{w}}$, temperature, coffee medium and their interactions using the Kruskal-Wallis test (non-normality data).

\begin{tabular}{|c|c|c|c|c|}
\hline Strain & Temperature & Media Type & Water Activity & Response \\
\hline \multirow[t]{2}{*}{ A. westerdijkiae (2A3) } & S & NS & S & Growth \\
\hline & S & S & S & OTA $\left(\operatorname{ng~g~}^{-1}\right)$ \\
\hline \multirow[t]{2}{*}{ A. westerdijkiae (C1/1) } & $S$ & S & $\mathrm{S}$ & Growth \\
\hline & $\mathrm{S}$ & NS & S & OTA $\left(\operatorname{ng~g~}^{-1}\right)$ \\
\hline \multirow[t]{2}{*}{ A. westerdijkiae (B 2) } & S & NS & S & Growth \\
\hline & $\mathrm{S}$ & S & S & OTA $\left(\operatorname{ng~g}^{-1}\right)$ \\
\hline \multirow[t]{2}{*}{ A. westerdijkiae (CBS 121986) } & S & NS & S & Growth \\
\hline & $S$ & $S$ & $S$ & OTA $\left(\mathrm{ng} \mathrm{g}^{-1}\right)$ \\
\hline
\end{tabular}

Significance based on $p \leq 0.05$; NS, not significant; S, significant.

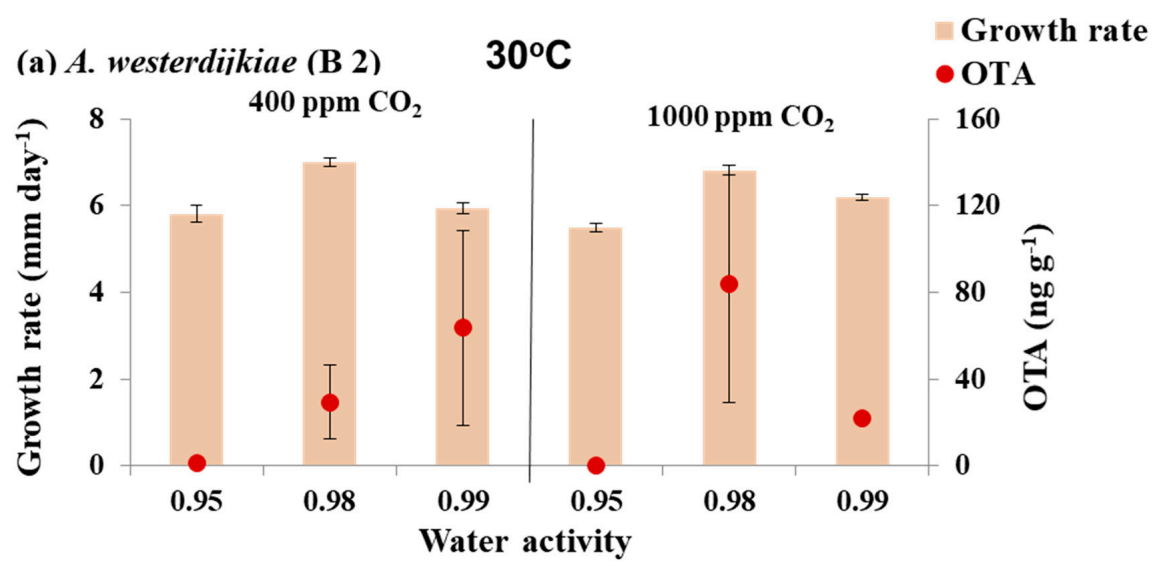

(b) A.westerdijkiae (CBS 121986)

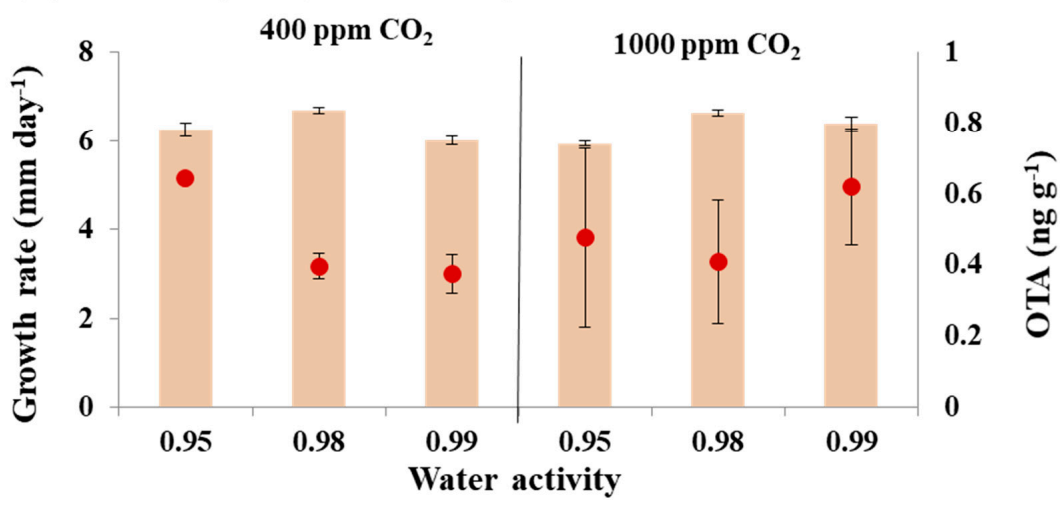

Figure 3. Effect of water activity $\times \mathrm{CO}_{2}$ exposure at $30^{\circ} \mathrm{C}$ on growth $\left(\mathrm{mm} \mathrm{day}^{-1}\right)$ and ochratoxin $\mathrm{A}$ $\left(\mathrm{ng} \mathrm{g}^{-1}\right)$ production by strains of $A$. westerdijkiae $(\mathbf{a}, \mathbf{b})$ on a $6 \%$ green coffee extract agar after 10 days incubation. Bars represent SEM. Please note that $Z$-axis has different ranges for OTA production. 
(a) A. westerdijkiae (B 2)

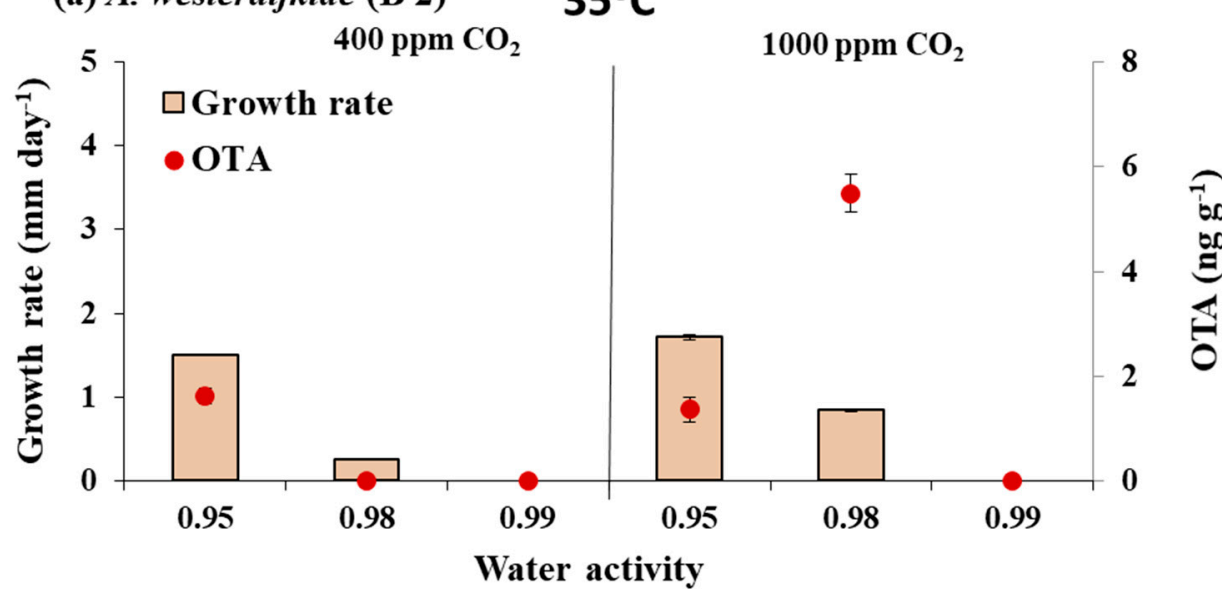

(b) A.westerdijkiae (CBS 121986)

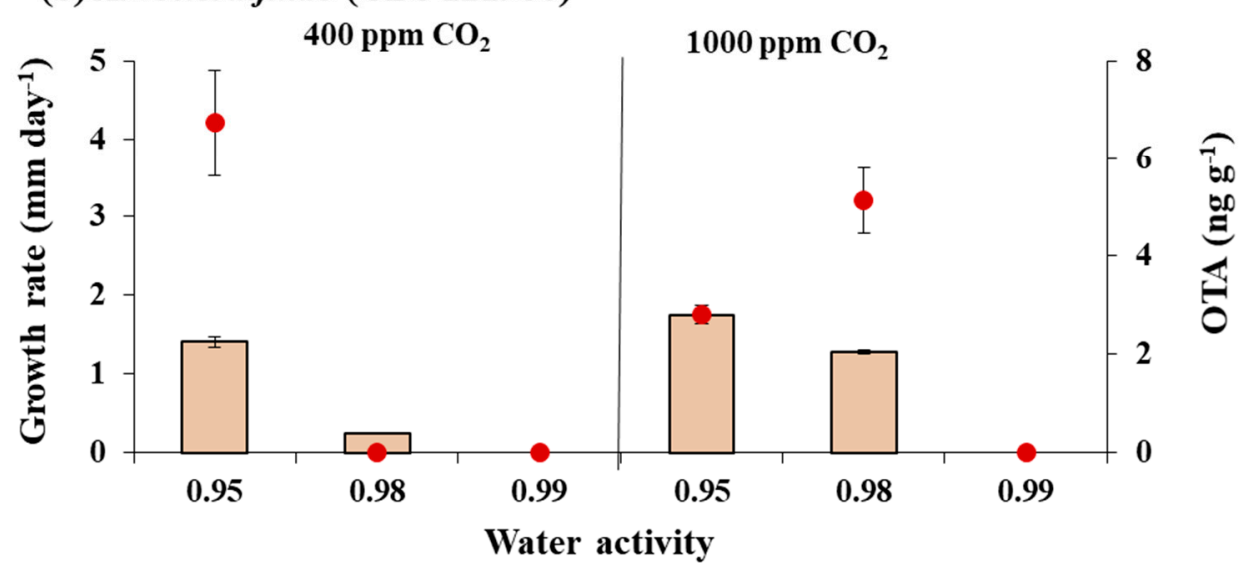

Figure 4. Effect of water activity $\times \mathrm{CO}_{2}$ exposure at $35^{\circ} \mathrm{C}$ on growth $\left(\mathrm{mm} \mathrm{day}^{-1}\right)$ and ochratoxin $\mathrm{A}$ $\left(\mathrm{ng} \mathrm{g}^{-1}\right)$ production by strains of $A$. westerdijkiae $(\mathbf{a}, \mathbf{b})$ on a $6 \%$ green coffee extract agar after 10 days incubation. Bars represent SEM.

Statistically, the factors assayed (water activity and $\mathrm{CO}_{2}$ ), as well as their interactions, had a significant effect on mycelial growth for the strains examined at 30 and $35{ }^{\circ} \mathrm{C}$ using the Kruskal-Wallis and ANOVA tests (Table 3). Growth was significantly $(p<0.05)$ affected by elevated $\mathrm{CO}_{2}$ at $30^{\circ} \mathrm{C}$ and 0.95 and $0.99 \mathrm{a}_{\mathrm{w}}$ for the two A. westerdijkiae strains at all $\mathrm{a}_{\mathrm{w}}$ levels. At $35^{\circ} \mathrm{C}$, there was a statistically significant effect on growth for the strains. The effect of the various factors and their interactions were more significant at $35^{\circ} \mathrm{C}$ than at $30^{\circ} \mathrm{C}$. Changing temperature from 30 to $35^{\circ} \mathrm{C}$ had a significant effect on growth.

\subsubsection{In Vitro Effects of Climate-Related Interaction of Abiotic Conditions on OTA Production}

Figures 3 and 4 also show the effect of the three-way interacting climate-related factors on in vitro OTA production by the strains of $A$. westerdijkiae. There was little effect of elevated $\mathrm{CO}_{2}$ on OTA production at $30^{\circ} \mathrm{C}$. However, OTA production was reduced slightly when exposed to $1000 \mathrm{ppm} \mathrm{CO}_{2}$ especially at $0.97 \mathrm{a}_{\mathrm{w}}$.

When the temperature was increased to $35^{\circ} \mathrm{C}$ in the presence of elevated $\mathrm{CO}_{2}$ (1000 ppm), there was a stimulation effect on OTA production at $0.98 \mathrm{a}_{\mathrm{w}}$ by the two A. westerdijkiae strains. Thus, for strain B 2 there was a significant stimulation under water stress at $0.90 \mathrm{a}_{\mathrm{w}}$, with OTA production increased from about 7.0 to $680 \mathrm{ng} \mathrm{g}^{-1}$ when exposed to $1000 \mathrm{ppm} \mathrm{CO}_{2}$.

Statistically, OTA production was significantly affected by elevated $\mathrm{CO}_{2}, \mathrm{a}_{\mathrm{w}}$ and the interaction between $\mathrm{a}_{\mathrm{w}}$ and elevated $\mathrm{CO}_{2}$ at 30 and $35^{\circ} \mathrm{C}$ (Table 4). 
Table 3. Summary of statistical effects on growth rate of the strains of $A$. westerdijkiae in relation to $\mathrm{CO}_{2}$, water activity $\left(\mathrm{a}_{\mathrm{W}}\right)$ and $\mathrm{CO}_{2}$ at 30 and $35^{\circ} \mathrm{C}$ on a $6 \%$ green coffee extract medium using Kruskal-Wallis (non-normality data) and ANOVA (normality data) tests.

\begin{tabular}{|c|c|c|c|c|}
\hline \multicolumn{5}{|c|}{ Temperature $30^{\circ} \mathrm{C}$} \\
\hline Strains & $\mathrm{CO}_{2}(1000 \mathrm{ppm})$ & Water Activity $\left(a_{w}\right)$ & $\mathrm{CO}_{2} \times \mathrm{a}_{\mathrm{w}}$ & Response \\
\hline A. westerdijkiae (B 2) & $\mathrm{NS}^{\mathrm{a}}$ & $\mathrm{S}^{\mathrm{b}}$ & $\mathrm{NS}^{\mathrm{a}}$ & growth rate \\
\hline A. westerdikiae (CBS 121986) & $\mathrm{S}^{\mathrm{a}}$ & $\mathrm{NS}^{\mathrm{a}}$ & - & growth rate \\
\hline \multicolumn{5}{|c|}{ Temperature $35^{\circ} \mathrm{C}$} \\
\hline A. westerdijkiae (B 2) & $\mathrm{NS}^{\mathrm{b}}$ & $S^{b}$ & $\mathrm{NS}^{\mathrm{a}}$ & growth rate \\
\hline A. westerdijkiae (CBS 121986) & $\mathrm{NS}^{\mathrm{a}}$ & $\mathrm{S}^{\mathrm{a}}$ & - & growth rate \\
\hline \multicolumn{5}{|c|}{ Temperatures 30 and $35^{\circ} \mathrm{C}$} \\
\hline Strains & $\mathrm{CO}_{2}(1000 \mathrm{ppm})$ & $a_{w}$ & $\operatorname{Temp}\left(30+35^{\circ} \mathrm{C}\right)$ & Response \\
\hline A. westerdijkiae (B 2) & $\mathrm{NS}^{\mathrm{a}}$ & $\mathrm{NS}^{\mathrm{a}}$ & $\mathrm{S}^{\mathrm{a}}$ & growth rate \\
\hline A. westerdijkiae (CBS 121986) & $\mathrm{NS}^{\mathrm{a}}$ & $\mathrm{S}^{\mathrm{a}}$ & $\mathrm{S}^{\mathrm{a}}$ & growth rate \\
\hline
\end{tabular}

Key: ${ }^{a}$, Kruskal-Wallis test; ${ }^{\mathrm{b}}$, ANOVA; NS, not significant; $\mathrm{S}$, significant $(p \leq 0.05)$.

Table 4. Summary of statistical results for the OTA production by the strains of $A$. westerdijkiae in relation to $\mathrm{a}_{\mathrm{w}}$, temperature and $\mathrm{CO}_{2}$ using Kruskal-Wallis (non-normality data) and ANOVA (normality data) tests.

\begin{tabular}{|c|c|c|c|}
\hline Strains & $\mathrm{CO}_{2}(1000 \mathrm{ppm})$ & $a_{w}$ & $\mathrm{CO}_{2} \times \mathrm{a}_{\mathrm{w}}$ \\
\hline A. westerdijkiae (B 2) & $S^{a}$ & $\mathrm{~S}^{\mathrm{a}}$ & - \\
\hline A. westerdijkiae (CBS 121986) & $\mathrm{NS}^{\mathrm{b}}$ & $\mathrm{S}^{\mathrm{b}}$ & $\mathrm{NS}^{\mathrm{b}}$ \\
\hline \multicolumn{4}{|c|}{ Temperature $35^{\circ} \mathrm{C}$} \\
\hline A. westerdijkiae (B 2) & $\mathrm{S}^{\mathrm{a}}$ & $\mathrm{S}^{\mathrm{a}}$ & - \\
\hline A. westerdijkiae (CBS 121986) & $\mathrm{S}^{\mathrm{a}}$ & $S^{a}$ & - \\
\hline \multicolumn{4}{|c|}{ Temperature 30 and $35^{\circ} \mathrm{C}$} \\
\hline Strains & $\mathrm{CO}_{2}(1000 \mathrm{ppm})$ & $\mathbf{a}_{\mathbf{w}}$ & Temp $30+35$ \\
\hline A. westerdijkiae (B 2) & $\mathrm{S}^{\mathrm{a}}$ & $\mathrm{S}^{\mathrm{a}}$ & $\mathrm{S}^{\mathrm{a}}$ \\
\hline A. westerdijkiae (CBS 121986) & $\mathrm{S}^{\mathrm{a}}$ & $S^{a}$ & $S^{b}$ \\
\hline
\end{tabular}

Key: ${ }^{\text {a }}$, Kruskal-Wallis test; ${ }^{\mathrm{b}}$, ANOVA; NS, not significant; $\mathrm{S}$, significant $(p \leq 0.05)$.

3.3. In Situ Effect of Water Activity $\times$ Elevated $\mathrm{CO}_{2} \times$ Temperature on OTA Production at 30 and $35^{\circ} \mathrm{C}$ in Stored Coffee Beans by A. westerdijkiae Strains

Table 5 shows the effect of climate-related factors ( 30 vs. $35^{\circ} \mathrm{C} ; 400$ vs. 1000 ppm $\mathrm{CO}_{2} ; 0.90$, 0.95 and $0.97 \mathrm{a}_{\mathrm{w}}$ ) on OTA production by the strains of $A$. westerdijkiae examined. High amounts of OTA were produced by these two strains of $A$. westerdijkiae at 0.90 and $0.95 \mathrm{a}_{\mathrm{w}}$ in elevated $\mathrm{CO}_{2}(1000 \mathrm{ppm})$ at $30{ }^{\circ} \mathrm{C}$. In some cases there was some stimulation by elevated $\mathrm{CO}_{2}$ at $30^{\circ} \mathrm{C}$, especially under water stress. This produced 4598.8 (B 2 strain) and $3974.2 \mathrm{ng} \mathrm{g}^{-1}$ (CBS121896) at elevated $\mathrm{CO}_{2}$ in contrast to much lower amounts in the normal $400 \mathrm{ppm} \mathrm{CO}_{2}$ treatment levels.

When the temperature was increased from 30 to $35^{\circ} \mathrm{C}$, OTA production for these two strains was reduced at different $\mathrm{a}_{\mathrm{w}}$ levels and $\mathrm{CO}_{2}(1000 \mathrm{ppm})$. They both produced more OTA when exposed to elevated $\mathrm{CO}_{2}$ at $35^{\circ} \mathrm{C}$.

Statistically, Table 6 shows that the effect of interacting $\mathrm{a}_{\mathrm{w}} \times$ elevated $\mathrm{CO}_{2}(1000 \mathrm{ppm}) \times$ temperature on the strains. There was a significant increase $(p=0.05)$ in OTA production in the presence of elevated $\mathrm{CO}_{2}$ at 0.90 and $0.97 \mathrm{a}_{\mathrm{w}} . \mathrm{A}_{\mathrm{W}}, \mathrm{CO}_{2}$ and their interaction significantly $(p<0.05)$ affected OTA production by the $\mathrm{B} 2$ strain in stored green coffee beans at $30{ }^{\circ} \mathrm{C}$. There were no effects of $\mathrm{a}_{\mathrm{w}}$ on the CBS type strain of $A$. westerdijkiae (CBS 121986). 
Table 5. Effect of interacting climate-related factors of water activity $\left(\mathrm{a}_{\mathrm{w}}\right)$, temperature $\left(30 \mathrm{vs} .35^{\circ} \mathrm{C}\right)$ and $\mathrm{CO}_{2}$ (400 vs. $1000 \mathrm{ppm}$ ) on the mean ochratoxin A contamination ( $\mathrm{ng} \mathrm{g}^{-1} \pm \mathrm{SE}$ ) of green coffee beans stored for 10 days after inoculation with each of the strains.

\begin{tabular}{cccccc}
\hline Temperature $\left({ }^{\circ} \mathbf{C}\right)$ & \multicolumn{2}{c}{30} & & 35 \\
\hline $\mathbf{C O}_{2}$ Concentration $(\mathbf{p p m})$ & & 400 & $\mathbf{1 0 0 0}$ & 400 & $\mathbf{1 0 0 0}$ \\
\hline Strains & $\mathbf{a}_{\mathbf{w}}$ & & & & \\
\hline A. westerdijkiae (B 2) & 0.97 & $3976.9 \pm 603.7$ & $2760.4 \pm 52.7$ & $175.6 \pm 0.2$ & $14.4 \pm 3.7$ \\
\hline & 0.95 & $4243.3 \pm 571.4$ & $4767.1 \pm 372.1$ & $128.8 \pm 31.6$ & $63.1 \pm 21.3$ \\
\hline A. westerdijkiae (CBS 121986) & 0.90 & $1644.3 \pm 545.3$ & $4598.9 \pm 426.4$ & $8.2 \pm 0.2$ & $680.2 \pm 187.2$ \\
\hline & 0.97 & $2681.3 \pm 346.7$ & $3395.5 \pm 198.7$ & $8.1 \pm 0.4$ & $12.7 \pm 0.9$ \\
\hline & 0.90 & $2842.3 \pm 325.1$ & $3087.9 \pm 225.4$ & $8.2 \pm 0.6$ & $51.3 \pm 28.6$ \\
\hline
\end{tabular}

Table 6. Summary of statistical effect of climate-related abiotic factors on OTA production by the two strains of $A$. westerdijkiae in stored coffee beans examined in this study. Statistical analyses based on Kruskal-Wallis (non-normality data) and ANOVA (normality data) tests.

\begin{tabular}{|c|c|c|c|}
\hline \multicolumn{4}{|c|}{ Temperature $\left(30^{\circ} \mathrm{C}\right)$} \\
\hline Strains & $\mathrm{CO}_{2}$ & $a_{w}$ & $\mathrm{a}_{\mathrm{w}} \times \mathrm{CO}_{2}$ \\
\hline A. westerdijkiae (B 2) & $\mathrm{S}^{\mathrm{b}}$ & $\mathrm{S}^{\mathrm{b}}$ & $\mathrm{S}^{\mathrm{b}}$ \\
\hline A. westerdijkiae (CBS 121986) & $\mathrm{S}^{\mathrm{b}}$ & NS & NS \\
\hline \multicolumn{4}{|c|}{ Temperature $\left(35^{\circ} \mathrm{C}\right)$} \\
\hline A. westerdijkiae (B 2) & $\mathrm{S}^{\mathrm{a}}$ & $\mathrm{S}^{\mathrm{a}}$ & N/A \\
\hline A. westerdijkiae (CBS 121986) & $\mathrm{S}^{\mathrm{a}}$ & $\mathrm{NS}^{\mathrm{a}}$ & N/A \\
\hline Strains & $\mathrm{CO}_{2}(1000 \mathrm{ppm})$ & $\mathbf{a}_{\mathbf{w}}$ & Temp: $30+35^{\circ} \mathrm{C}$ \\
\hline A. westerdijkiae (B 2) & $\mathrm{NS}^{\mathrm{a}}$ & $\mathrm{NS}^{\mathrm{a}}$ & $S^{a}$ \\
\hline A. westerdijkiae (CBS 121986) & $\mathrm{S}^{\mathrm{a}}$ & $\mathrm{NS}^{\mathrm{a}}$ & $\mathrm{S}^{\mathrm{a}}$ \\
\hline
\end{tabular}

Key: S, significant $(p<0.05)$; NS, not significant $(p>0.05){ }^{\text {a }}$, Kruskal-Wallis test; ${ }^{\text {b }}$, ANOVA; N/A, not applicable.

\section{Discussion}

\subsection{In Vitro Effects of Climate-Related Abiotic Factors on Growth and OTA Production by Strains of A. westerdijkiae}

This study has examined the resilience of strains of $A$. westerdijkiae in relation to two-way interacting abiotic factors $\left(\mathrm{a}_{\mathrm{w}} \times\right.$ temperature $)$ and three-way interacting climate-related factors $\left(\mathrm{a}_{\mathrm{w}} \times\right.$ temperature $\times \mathrm{CO}_{2}$ ) on growth and OTA production in vitro on coffee extract-based matrices and stored coffee. Interestingly, while growth was similar on both green coffee extract and roasted coffee extract media, OTA production on the roasted coffee-based medium was practically undetectable. Certainly the strains were able to grow well over a wide range of temperatures, with reduced growth at $0.90 \mathrm{a}_{\mathrm{w}}$. This suggests that rapid colonization of drying green coffee would occur in the range of $25-35^{\circ} \mathrm{C}$ under $0.90-0.98 \mathrm{a}_{\mathrm{w}}$ conditions and result in a higher risk of OTA contamination. The two strains chosen for further studies did produce significant amounts of OTA, and were thus used for more detailed studies on the impact of three-way interacting climate-related abiotic factors.

Previous studies by Taniwaki et al. $[17,18]$ reported that $A$. ochraceus $(=A$. westerdijkiae) was primarily responsible for the OTA contamination of green coffee, suggesting a minimum $\mathrm{a}_{\mathrm{w}}$ for growth of about 0.85. Pardo et al. [19] suggested that in vitro growth on green coffee-based media was optimal for A. ochraceus ( $=$ A. westerdijkiae) strains at $0.95-0.99 \mathrm{a}_{\mathrm{W}}$ and $20-30{ }^{\circ} \mathrm{C}$. They suggested the $\mathrm{a}_{\mathrm{w}}$ 
minimum for germination was 0.80 , and for mycelial growth was $0.85 \mathrm{a}_{\mathrm{w}}$. Maximum OTA production for $A$. ochraceus occurred at $0.99 \mathrm{a}_{\mathrm{w}}$ with no toxin produced at $0.80 \mathrm{a}_{\mathrm{w}}$. Previous studies suggest that optimum OTA production by $A$. ochraceus $\left(=A\right.$. westerdijkiae) was at $0.95 \mathrm{a}_{\mathrm{w}}$, with no production at $0.90 \mathrm{a}_{\mathrm{w}}$. The maximum growth for the type strains of $A$. westerdijkiae on YES media occurred at $0.95 \mathrm{a}_{\mathrm{w}}$ and $30{ }^{\circ} \mathrm{C}$. Optimum OTA production was at $25^{\circ} \mathrm{C}$ [1]. Akbar et al. [13] used a 20\% coffee-extract medium that influenced relative growth rates and OTA production although optimum conditions, especially for growth, were relatively similar. With the exception of the work of Pardo et al. [19,20] and Akbar et al. [13], most of the other studies were carried out have used defined laboratory media instead of a heterogenous coffee-based medium. The latter medium may provide more useful data and may more accurately simulate what may occur in situ.

This study has shown the resilience of the strains of $A$. westerdijkiae to two-way interacting climatic conditions that form a platform for examining in more detail the effects of three-way interacting climate-related abiotic factors by including exposure to existing and elevated $\mathrm{CO}_{2}$ levels (400 vs. 1000 ppm) [3]. Coffee beans during the drying and storage phase may be exposed to these three-way interacting conditions, which will influence both the dominance of toxigenic fungal groups including those from the Aspergillus section Circumdati and the section Nigri species [13,21,22]. The present study has focused on one of the key species from the section Circumdati only. Studies have shown, however, that slightly elevated $\mathrm{CO}_{2}$ levels combined with drought stress and increased temperature may enhance OTA production by strains of $A$. westerdijkiae on green coffee-based media. Interestingly, the impact on OTA production appeared to be more pronounced than the effects on colonization rates. In addition, elevated $\mathrm{CO}_{2}(1000 \mathrm{ppm})+$ elevated temperature $\left(35^{\circ} \mathrm{C}\right)$ increased OTA production when compared with $30^{\circ} \mathrm{C}$ for one of the A. westerdijkiae strains (B 2). Both strains had optimum growth at $0.95 \mathrm{a}_{\mathrm{w}}$ and $35^{\circ} \mathrm{C}$, while at $30{ }^{\circ} \mathrm{C}$, the optimum was at $0.98 \mathrm{a}_{\mathrm{w}}$.

Most previous studies that have examined the impact of $\mathrm{a}_{\mathrm{w}} \times$ elevated $\mathrm{CO}_{2}$ have focused on modified atmosphere storage to try and control OTA production post-harvest in both coffee and other commodities. Cairns-Fuller et al. [23] suggested that $50 \% \mathrm{CO}_{2}$ was required to inhibit growth and OTA production by $P$. verrucosum in moist grain by $>75 \%$ at $0.90-0.995 \mathrm{a}_{\mathrm{w}}$. Paster et al. [24] reported that no growth of $A$. ochraceus ( $=$ A. westerdijkiae) occurred at 80 or $100 \% \mathrm{CO}_{2}$, and that growth was partially inhibited by $60 \% \mathrm{CO}_{2}$. Similarly, Pateraki et al. [25] found that $50 \% \mathrm{CO}_{2}$ inhibited A. carbonarius growth after five days. Some studies have reported a reduction in growth rate at $5-10 \%$ of $\mathrm{CO}_{2}$ for some species at low $\mathrm{a}_{\mathrm{w}}$ levels, including an increase in the lag phases prior to growth. Although at $\geq 15 \% \mathrm{CO}_{2}$ most strains showed growth inhibition, especially under water stress [26]. Valero et al. [27] found that there was a significant reduction in growth and OTA production by Aspergillus section Nigri species such as $A$. carbonarius and $A$. niger at $1 \% \mathrm{O}_{2}$ when combined with $15 \% \mathrm{CO}_{2}$.

Medina et al. [3] suggested that often while exposure of mycotoxigenic fungi such as $A$. flavus to interacting climate-related abiotic factors has little effect on growth, this does however result in a significant stimulation of aflatoxin $\mathrm{B}_{1}\left(\mathrm{AFB}_{1}\right)$ production on milled maize-based media and in stored maize. Indeed, recent studies have shown that the kinetics of $\mathrm{AFB}_{1}$ production change over time when this species is exposed to climate-related abiotic factors [28]. This is supported by relative expression of key structural and regulatory genes involved in the biosynthesis of aflatoxins. Mycotoxigenic fungi show significant plasticity in physiologically responding to stress factors, and thus three-way interacting stress factors may have a more significant impact on the colonization of different commodities and production of mycotoxins and other secondary metabolites by these toxigenic species.

\subsection{In Situ Effect of Three-Way Interacting Climate-Related Abiotic Factors on OTA Production in Stored Green Coffee}

This study examined the effects of three-way climate-related abiotic factors on contamination of stored green Arabica coffee beans with OTA when inoculated with individual strains of ochratoxigenic Aspergillus section Circumdati species. Based on the water adsorption curve, the range of $\mathrm{a}_{\mathrm{w}}$ levels used represent a moisture content (m.c.) of between approx. $40 \%$ and $20-22 \%$, which is equivalent to the 
range of $0.90-0.97 \mathrm{a}_{\mathrm{w}}$. This study has shown that there was a high OTA contamination of stored green coffee when colonized by $A$. westerdijkiae strains, especially at 0.95 and $0.97 \mathrm{a}_{\mathrm{w}}$ and $30{ }^{\circ} \mathrm{C}$, regardless of $\mathrm{CO}_{2}$ levels. At $35^{\circ} \mathrm{C}$, the OTA contamination levels were significantly lower than at $30^{\circ} \mathrm{C}$ regardless of other abiotic treatments. However, at $35^{\circ} \mathrm{C}$ there was higher OTA contamination levels in these two $A$. westerdijkiae strains at 0.95 and $0.90 \mathrm{a}_{\mathrm{w}}$ and $1000 \mathrm{ppm} \mathrm{CO}_{2}$. This suggests that the stress of interacting abiotic factors results in a stimulation of OTA production by this species.

Previously, Palacios-Cabrera et al. [15] found high amounts of OTA produced by A. carbonarius in irradiated raw coffee beans when stored at $100 \%$ Equilibrium Relative Humidity $\left(=1.00 \mathrm{a}_{\mathrm{w}}\right)$. Similarly, maximum growth rates of $A$. ochraceus on irradiated green coffee beans was found to occur at $30{ }^{\circ} \mathrm{C}$ and 0.95-0.99 $\mathrm{a}_{\mathrm{w}}$, which was similar to the in vitro studies in the present work. Other studies on irradiated coffee beans have shown OTA production between $40-17,000 \mathrm{ng} \mathrm{g}^{-1}$ over this $\mathrm{a}_{\mathrm{w}}$ range at $30{ }^{\circ} \mathrm{C}$ [20]. This study also showed that limited OTA was produced at $10{ }^{\circ} \mathrm{C}$ and $0.80 \mathrm{a}_{\mathrm{w}}$. It has been specified that during post-fermentation and drying, the final safe storage m.c. for green coffee beans should be in the range of $10-12 \%$ (approx. $0.65-0.70 \mathrm{a}_{\mathrm{w}}$ [29]). However, uneven drying can result in pockets of wetter coffee beans that are conducive to colonization by ochratoxigenic species.

Prior to the reclassification of the Aspergillus section Circumdati, Taniwaki et al. [18] found that there was very low accumulation of OTA by A. ochraceus $\left(=A\right.$. westerdijkiae) at $0.80 \mathrm{a}_{\mathrm{w}}$ and $25^{\circ} \mathrm{C}$, with an increased contamination at $0.95 \mathrm{a}_{\mathrm{w}}$ after three weeks storage. Bucheli et al. [22] also found the lowest $\mathrm{a}_{\mathrm{w}}$ levels for OTA contamination of green coffee by $A$. ochraceus $(=A$. westerdijkiae) were 0.85 and $20-30{ }^{\circ} \mathrm{C}$. However, these earlier studies did not examine the effects of $>30{ }^{\circ} \mathrm{C}$ on interactions with other abiotic factors, especially water stress and elevated $\mathrm{CO}_{2}$. Akbar et al. [7] found that there were differential effects of three-way interacting climate-related abiotic factors on species of the section Circumdati and section Nigri. The species from the latter group (A. carbonarius, A. niger) appeared to be less affected by such abiotic changes and thus had a better resilience to such conditions. This may of course have implications, such as the fungal community structure and dominance of different toxigenic species colonizing the ripening coffee cherries pre-harvest, and post-harvest drying and processing may change under climate-related conditions and influence both colonization and mycotoxin contamination in the coffee production chain $[3,5]$.

In the in situ study only Arabica coffee beans were used. There are significant and inherent differences in the caffeine concentration between this type (0.6\%) and Robusta (4\%) [30]. Caffeine has been shown to have some anti-fungal inhibitory effects and can inhibit both growth and mycotoxin production significantly. For example, Akbar et al. [21] showed that $0.5-1.0 \%$ caffeine inhibited growth of toxigenic species from both Section Circumdati and Nigri groups on a conducive defined medium. Thus, it may be important to compare the effect of climate-related abiotic factors on the colonization of both Arabica and Robusta coffee beans to evaluate and compare the impacts on OTA production. Inherent caffeine concentrations may inhibit colonization by some toxigenic species and perhaps influence the levels of OTA contamination that may occur. Robusta coffee beans are mainly grown at lower altitudes, and may have better tolerance to climate-related abiotic factors than Arabica, which is grown at higher altitudes and may be more sensitive to climate-related agronomic factors [31]. In addition, changes in diversity of pests could lead to increased damage to ripening coffee beans, and such damage has been shown to have an impact on infection by toxigenic fungi and perhaps also toxin contamination levels post-harvest [32].

Other important abiotic factors have not been considered such as UV radiation and fluctuations in temperature $\times$ water availability and exposure to elevated $\mathrm{CO}_{2}$ conditions [32,33]. Some of these factors have been shown to impact growth and OTA production by strains of $A$. carbonarius isolated from grapes [33]. The impact of acclimatization of strains of species from both sections Circumdati and Niger have not been addressed. Studies by Vary et al. [34] on Fusarium graminearum and by Medina et al. [3] on $A$. flavus have shown that exposing these species to elevated $\mathrm{CO}_{2}$ conditions for $10-20$ generations can result in enhanced tolerance and pathogenicity and lead to increased mycotoxin production. 


\section{Conclusions}

This study has shown that in terms of colonization of both green and roasted coffee-based matrices strains of $A$. westerdijkiae have very good resilience to two-way climate-related interacting abiotic factors. However, on media made from roasted coffee beans there was very little OTA contamination when compared to that of green coffee-based media. Three-way interacting abiotic climate related factors had some effect on growth of the strains of $A$. westerdijkiae, especially at $35^{\circ} \mathrm{C}$ and $0.98-0.95 \mathrm{a}_{\mathrm{w}}$ with elevated $\mathrm{CO}_{2}$. However, there was significant stimulation of OTA production. The data suggest that in stored green coffee beans, A. westerdijkiae is able to produce OTA when temperature is increased to $35^{\circ} \mathrm{C}+1000 \mathrm{ppm} \mathrm{CO}$ and drought stress is imposed. The present studies used gamma-irradiated coffee beans that had no competition from the resident natural surface mycobiota. Studies are needed to examine how such interactions may affect the resilience of ochratoxigenic fungi and the contamination of different coffee cultivars with OTA. However, the type of data presented in this study is essential for the development of more accurate models to determine the relative risk of OTA in the coffee production and processing chain.

Author Contributions: A.A. carried out the laboratory research work. A.M. and N.M. devised this as part of a PhD project and co-supervised the research work. All authors contributed to the writing, with N.M. completing the final submitted version. All authors have read and agreed to the published version of the manuscript.

Funding: This was part of PhD research project to A.A. funded by the Kuwaiti Government.

Acknowledgments: A. Akbar is very grateful to the Kuwaiti Government for the $\mathrm{PhD}$ scholarship. We are also very grateful to B. Patino (Complutense University, Madrid, Spain) for the type strain.

Conflicts of Interest: The authors declare no conflict of interest.

\section{References}

1. Abdel-Hadi, A.; Magan, N. Influence of environmental factors on growth, sporulation and ochratoxin A and B production of the new grouping of the A. ochraceus group. World Mycotoxin J. 2009, 2, 429-434. [CrossRef]

2. European Commission Recommendation No 2006/576 of 17 August 2006 on the presence of deoxynivalenol, zearalenone, ochratoxin A, T-2 and HT-2 and fumonisins in products intended for animal feeding. Off. J. Eur. Union 2006, 229, 7-9.

3. Magan, N.; Medina, A. Integrating gene expression, ecology and mycotoxin production by Fusarium and Aspergillus species in relation to interacting environmental factors. World Mycotoxin J. 2016, 9, 863-874. [CrossRef]

4. Medina, A.; Akbar, A.; Baazeem, A.; Rodriguez, A.; Magan, N. Climate change, food security and mycotoxins: Do we know enough. Fungal Biol. Rev. 2017, 31, 143-154. [CrossRef]

5. Paterson, R.R.M.; Lima, N. How will climate change affect mycotoxins in food. Food Res. Int. 2010, 43, 1902-1914. [CrossRef]

6. Wu, F.; Bhatnagar, D.; Bui-Klimke, T.; Carbone, I.; Hellmich, R.; Munkvold, G.; Paul, P.; Payne, G.; Takle, E. Climate change impacts on mycotoxin risks in US maize. World Mycotoxin J. 2011, 4, 79-93. [CrossRef]

7. Akbar, A.; Medina, A.; Magan, N. Impact of climate change factors on growth and ochratoxin A production by Aspergillus sections Circumdati and Nigri species on coffee. World Mycotoxin J. 2016, 9, 863-874. [CrossRef]

8. Magan, N.; Baxter, E.S. Effect of elevated $\mathrm{CO}_{2}$ and temperature on the phyllosphere mycoflora of winter wheat flag leaves during ripening. Ann. Appl. Biol. 1999, 129, 189-195. [CrossRef]

9. Ramos, A.J.; Magan, N.; Sanchis, V. Osmotic and matric potential effects on growth, sclerotial production and partitioning of polyols and sugars in colonies and spores of Aspergillus ochraceus. Mycol. Res. 1999, 103, 141-147. [CrossRef]

10. Abdelmohsen, S.; Verheecke-Vaessen, C.; Garcia-Cela, E.; Medina, A.; Magan, N. Solute and matric potential stress and Penicillium verrucosum: Impact on growth, gene expression and ochratoxin A production. World Mycotoxin J. 2020, 13, 345-351. [CrossRef]

11. Gilbert, M.K.; Medina, A.; Mack, B.M.; Lebar, M.; Rodriguez, A.; Bhatnagar, D.; Magan, N.; Obrian, G.; Payne, G. Carbon dioxide mediates the response to temperature and water activity levels in Aspergillus flavus during infection of maize kernels. Toxins 2018, 10, 5. [CrossRef] [PubMed] 
12. Vaughan, M.; Block, A.; Christensen, S.A.; Allen, L.H.; Schmelz, E.A. The effect of climate change associated abiotic stressors on phytochemical defences. Phytochem. Rev. 2017, 17, 37-49. [CrossRef]

13. Vaughan, M.; Huffaker, A.; Schmelz, E.A.; Dafoe, N.J.; Christensen, S.; Sims, J.; Martins, V.F.; Swerbilow, J.A.Y.; Romero, M.; Alborn, H.T.; et al. Effects of elevated $\left[\mathrm{CO}_{2}\right]$ on maize defense against mycotoxigenic Fusarium verticillioides. Plant. Cell Environ. 2014, 37, 2691-2706. [CrossRef] [PubMed]

14. Verheecke-Vaessen, C.; Diez-Gutierrez, L.; Renaud, J.; Sumarah, M.; Medina, A.; Magan, N. Interacting climate change environmental factors effects on Fusarium langsethiae growth, expression of TRI genes and T-2/HT-2 mycotoxin production on oat-based media and in stored oats. Fungal Biol. 2019, 123, 617-623. [CrossRef] [PubMed]

15. Palacios-Cabrera, H.; Taniwaki, M.H.; Menezes, H.C.; Iamanaka, B.T. The production of ochratoxin A by Aspergillus ochraceus in raw coffee at different equilibrium relative humidity and under alternating temperatures. Food Cont. 2004, 15, 531-535. [CrossRef]

16. Sultan, Y.; Magan, N.; Medina, A. Comparison of five different C18 HPLC analytical columns for the analysis of ochratoxin A in different matrices. J. Chromat. B 2014, 971, 89-93. [CrossRef]

17. Taniwaki, M.H.; Teixeira, A.A.; Teixeira, A.R.R.; Copetti, M.V.; Iamanaka, B.T. Ochratoxigenic fungi and ochratoxin A in defective coffee beans. Food Res. Int. 2014, 61, 161-166. [CrossRef]

18. Taniwaki, M.H.; Pitt, J.I.; Copetti, M.V.; Teixeira, A.A.; Iamanaka, B.T. Understanding Mycotoxin Contamination Across the Food Chain in Brazil: Challenges and Opportunities. Toxins 2019, 11, 411. [CrossRef]

19. Pardo, E.; Ramos, A.J.; Sanchis, V.; Marin, S. Modelling of effects of water activity and temperature on germination and growth of ochratoxigenic isolates of Aspergillus ochraceus on a green coffee-based medium. Int. J. Food Microbiol. 2005, 98, 1-9. [CrossRef]

20. Pardo, E.; Marin, S.; Ramos, A.J.; Sanchis, V. Effect of water activity and temperature on mycelial growth and Ochratoxin A production by isolates of Aspergillus ochraceus on irradiated green coffee beans. J. Food Prot. 2005, 68, 133-138. [CrossRef]

21. Akbar, A.; Medina, A.; Magan, N. Efficacy of different caffeine concentrations on growth and ochratoxin A production by Aspergillus section Nigri and Circumdati species. Lett. Appl. Microbiol. 2016, 63, 25-29. [CrossRef] [PubMed]

22. Bucheli, P.; Taniwaki, M.H. Research on the origin, and on the impact of post-harvest handling and manufacturing on the presence of ochratoxin A in coffee. Food Addit. Contam. 2002, 19, 655-665. [CrossRef] [PubMed]

23. Cairns-Fuller, V.; Aldred, D.; Magan, N. Water, temperature and gas composition interactions affect growth and ochratoxin A production by isolates of Penicillium verrucosum on wheat grain. J. Appl. Microbiol. 2005, 99, 1215-1221. [CrossRef] [PubMed]

24. Paster, N.; Lisker, N.; Chet, I. Ochratoxin A pro-duction by Aspergillus ochraceus Wilhelm grown undercontrolled atmospheres. Appl. Environ. Microbiol. 1983, 45, 1136-1139. [CrossRef] [PubMed]

25. Pateraki, M.; Dekanea, A.; Mitchell, D.; Lydakis, D.; Magan, N. Efficacy of sulphur dioxide, controlled atmospheres and water availability on in vitro germination, growth and ochratoxin A production by strains of Aspergillus carbonarius from grapes and vine fruits. Postharvest Biol. Technol. 2007, 44, 141-149. [CrossRef]

26. Magan, N.; Lacey, J. The effect of gas composition and water activity on growth of field and storage fungi and their interactions. Trans. British. Mycol. Soc. 1984, 82, 305-314. [CrossRef]

27. Valero, A.; Begum, M.; Hocking, A.D.; Marín, S.; Ramos, A.J.; Sanchis, V. Mycelial growth and ochratoxin A production by Aspergillus section Nigri on simulated grape medium in modified atmospheres. J. Appl. Microbiol. 2008, 105, 372-379. [CrossRef]

28. Garcia-Cela, E.; Verheecke-Vaessen, C.; Gutierrez-Pozo, M.; Kiaitsi, E.; Gasperini, A.M.; Magan, N.; Medina, A. Unveiling the effect of interacting forecasted abiotic factors on growth and Aflatoxin B1 production kinetics by Aspergillus In Flavus. Fungal Biol. 2020. [CrossRef]

29. Leitao, A.L. Occurrence of Ochratoxin A in Coffee: Threads and Solutions-A Mini-Review. Beverages 2019, 5, 36. [CrossRef]

30. Oestreich-Janzen, S. Chemistry of coffee. In Comprehensive Natural Products II: Chemistry and Biology; Mander, L., Liu, H.W., Eds.; Elsevier: Amsterdam, Holland, 2010; Volume 3, pp. 1085-1117.

31. Paterson, R.; Lima, N.; Taniwaki, M.H. Coffee, Mycotoxins and Climate Change. Food Res. Int. 2014, 61, 1-15. [CrossRef] 
32. Garcia-Cela, E.; Marin, S.; Sanchis, V.; Crespo-Sempere, A.; Ramos, A.J. Effect of ultraviolet radiation A and $\mathrm{B}$ on growth and mycotoxin production by Aspergillus carbonarius and Aspergillus parasiticus in grape and pistachio nuts. Fungal Biol. 2015, 119, 67-78. [CrossRef] [PubMed]

33. Cervini, C.; Verkeecke-Vaessen, C.; Ferrara, M.; García-Cela, E.; Magistàa, D.; Medina., A.; Gallo, A.; Magan, N.; Perron, G. Interacting climate change factors $\left(\mathrm{CO}_{2}\right.$ and temperature cycles) on growth, secondary metabolite gene expression and phenotypic ochratoxin A production by Aspergillus carbonarius strains on a grape-based matrix. Fungal Biol. 2020. [CrossRef]

34. Vary, Z.; Mullins, E.; Mcelwain, J.C.; Doohan, F. The severity of wheat diseases increases when plants and pathogens are acclimatised to elevated carbon dioxide. Glob. Chang. Biol. 2015, 21, 2661-2669. [CrossRef] [PubMed]

(C) 2020 by the authors. Licensee MDPI, Basel, Switzerland. This article is an open access article distributed under the terms and conditions of the Creative Commons Attribution (CC BY) license (http://creativecommons.org/licenses/by/4.0/). 